\title{
4. KAZEEM OLOJO: A PROFESSIONAL PAINTER AND AN ART INSTRUCTOR UNIVERSAL STUDIOS OF ART, LAGOS, NIGERIA
}

\author{
Augustine Okola Bardi ${ }^{107}$
}

\begin{abstract}
The works of art are priceless going by the quality of works exhibited by an artist. The artist tends to describe a particular scene near to the natural object in question. In the $15^{\text {th }}$ and $16^{\text {th }}$ centuries, France relayed on the impressionists who graduated from workshops and schools of apprentice in the likes of Gauguin, Monet, Manet, Degas, Renoir Cezanne, Delacroix and others to capture scenes of the Parisian country side that existed long age. The artist and his works remain indispensible to the existing societies. This form of art venture is not new to Nigeria where schools and workshops of apprenticeship exist. In Nigeria, the existing heritage and traditions if not for the artists will not be translated into art by the artists particularly painters like Dale, Oshinowo, Oguntokun, Emokpae, El-Dragg and others. The existence of workshops and schools of learning art have trained more artists to keep the aesthetical values of art. The society would be no doubt an unpleasant community without a touch of the arts. The artists who on daily bases create by painting, sculpting to make the environment a pleasurable place remain an important factor in the society,
\end{abstract}

Key words: Workshops and Schools, Apprenticeship, Heritage and Traditions, Aesthetical values, Society

\section{Introduction}

The importance of schools and workshops in Nigeria has helped to the development of art in the society for many years now. Many cities in Nigeria cannot do without the activities of very talented roadside artists who distinguished themselves in the production of sign post, banners, and prints on ceremonial T-shirts, umbrellas, plastic caps, mugs and many more. These artists were groomed in schools and workshops of apprenticeship, their capabilities are not doubting putting into consideration the output of their works, The sixties saw the establishment of the Mbari Mbayo, Ife and Ibadan schools, the successful Ori-Olokun experimental workshop, the Abayomi Barber school, the Bruce Onabrakpeya Harmattan workshop, the Universal Studios of Art led by Olabisi Onawale Fakeye, a center of instructors and participants.

These centers taught stylistic and expressive art that rank among the best in Nigeria. Also, these centers of art excellences disseminate the practice of painting, ceramics, graphic design, bead-making, sculpture, tie and dye, batik, metal design and many others. The lucky beneficiaries are the youths and adults both formal and non-formally trained artists in the society. The focus of this article therefore is on Kazeem Olojo a painter of good grade who trained at the Universal Studios of Art before studying fine art at the University of Benin, Benin City, and now an art instructor at the Universal Studios his alma mater.

\footnotetext{
${ }^{107}$ Associate Professor PhD., University of Benin, from Benin City, Nigeria, email: bardi.austin@yahoo.com
} 


\section{His Early Life and Education}

Kazeem Olojo was born on the $18^{\text {th }}$ of February, 1970 in Lagos State. He started his primary education at the Lagos Premier Day School in 1976 and completed it in 1983. During his primary school days, he had much encouragement from his parents and grandparents, most especially his father who was a renowned sculptor and a flying boat carver, from the Olojo Kosoko family of Lagos. The carving activities of his father also encouraged the young Kazeem who started carving boats with a group of young boys in the locality. Boat production a trade the family is known for flourished, to an extent that apprentices from the Republic of Benin, Togo and even as far as Ghana, came to learn the trade of boat building. Seeing the remarkable and importance of attendance to this lucrative trade and going by the number of participants, Kazeem's Father reached out for more instructors to teach and build more boats in Lagos. Kazeem over these years never let go this opportunity as he invited some friends to learn the trade of boat building.

During this period this period also, his carving skills continued to blossom at the Oke-Odo Community High School from 1989 to 1993. After his secondary education, he studied at the Lagos State Polytechnic from 1993 to 1996, and graduated with a National Diploma (ND) in textile design. As a young artist, Kazeem got inspiration from all kinds of structural buildings along his way daily, while going and coming from school. He was privileged to practice at the Universal Studios of Art under Bisi Fakeye as an Industrial Trainee in 1995. After his industrial training, he worked with SAIC International Company at Orile-Oyigbo. It was his passion to work with this company, since his early school days, when he used to walk through some structural building erected by the company. He also worked with Babs Dasofunjo and Associates, a building consultant in Lagos, who also had other branches in Abuja, Ibadan and Sagamu all popular cities in Nigeria. (An Interview, 2011).

\section{His Experiences and Experimentations}

According to Kremarikova and Kovacova in their selected art therapeutic programmes, mentioned the usefulness of art not only for social rehabilitation, social education, but that it is in another way to supporting the growth of art to be relevant to art therapy in disable children and others in the society. The society cannot advance without a touch of art educational initiative ( Kremarikova, Z.T. and Kovacova, B. 2016, pp. 277-278). Kazeem Olojo was opportune to undergo artistic training under Abiodun Olaku before he enrolled to study fine art at the University of Benin, Benin City, Nigeria where he was exposed to creative activities. He was influenced by his lecturers like Mr. Augustine Bardi, Mr. Manasseh Imonikebe, Mrs. Priscilla Aletor and Mr. ElDragg Okwujo. At this period, his painting skills and styles improved tremendously because of competitions among his mates. What he acquired as skills and styles from the Universal Studios of Art kept occurring in his paintings; (An Interview, 2011), particularly the vibrancy of his colours. He rejoined the Universal Studios of Art as a member in 2005 after his studies at the 
University of Benin. Pasca writes on the art of music education among the Proma and non Proma students which is based on discipline exercises that embraces creativity, aesthetics, artworks of musical creations in the development where experimentations, expressions, professionalism and colours plays a captivating role ( Pasca, E.M., 2015, pp. 323-328). She writes further on music wealth, human communication in schools of learning to the perfection of musical art. The Universal Studios of Art (USA), is center of experimental art appreciation where Kazeem joined to disseminate art knowledge.

His arrival at the studios fortunately stimulated the arrival of new participants who came to register as students on industrial training, as apprentices and as artists who would want to improve their skills in the arts. Kazeem's tutorship to participants which includes youths, adults both formally and informally under his care, was noticeable to a point that the founder and leader of the Universal Studios of Art, Bisi Fakeye selected ten newly admitted participants in painting under his care in 2013. He gladly accepted the offer and by 2014 , a year later, the participants graduated and were admitted as freshmen into higher institutions of learning, six into the University to study Fine and Applied Arts and four into Yaba College of Technology, Yaba, Lagos, Nigeria to study Graphics and Photography (Bardi, 2014, p. 223). His non-stop activities and attitude to painting projected his craftsmanship that reflects positively on his works as follows:

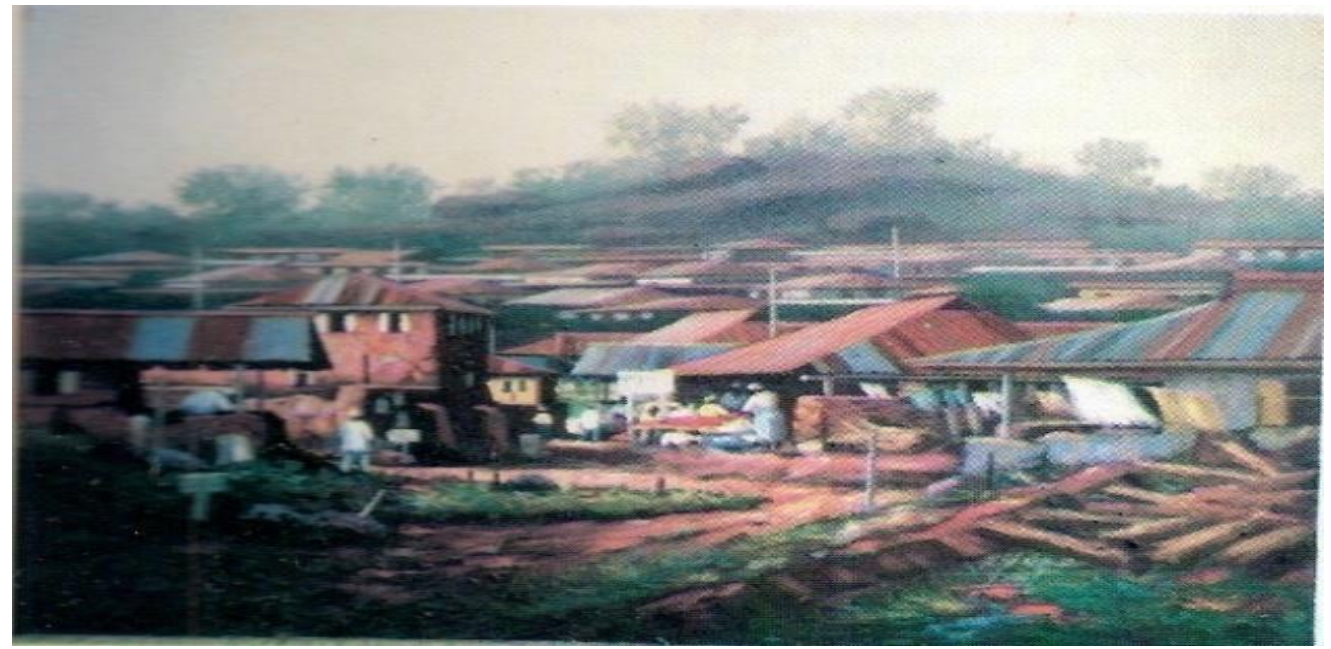

Fig.1: Reflections of a Setting. Kazeem Olojo, Size: $130 \mathrm{~cm} x 200 \mathrm{~cm}$.Oil on Canvas, 2007.

(c) Universal Studios of Art

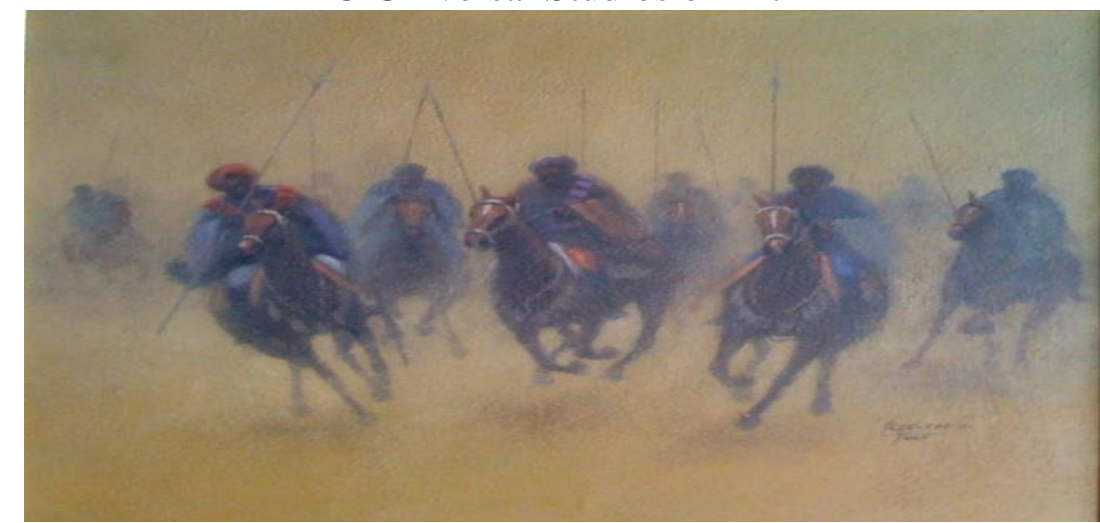

Fig. 2: Rampage. Kazeem Olojo. Oil on Canvas, 2008, Size: $180 \mathrm{~cm}$ x $150 \mathrm{~cm}$.

(C) Universal Studios of Art 
In the Reflections of a Setting (Fig. 1), the artist shows the view of a rural community with rustic roofing sheets, hanged and floating cloths, and people moving up and down, logs of wood and other paraphernalia of living. He presents a mountain at the background in natural colour, and treats all items in the foreground with detail (Maduka, 1999, pp. 20-21). Olojo paints Rampage (Fig. 2) with a convincing study of 'rampaging horses' that he has probably seen at a Durbar show. He captures the horses with accuracy, and depicts the horse riders in an exciting mood as reflected in the fluid movement of the horses. The riders are dressed in purple, black and red, and this colour combination adds glamour to the fiesta.

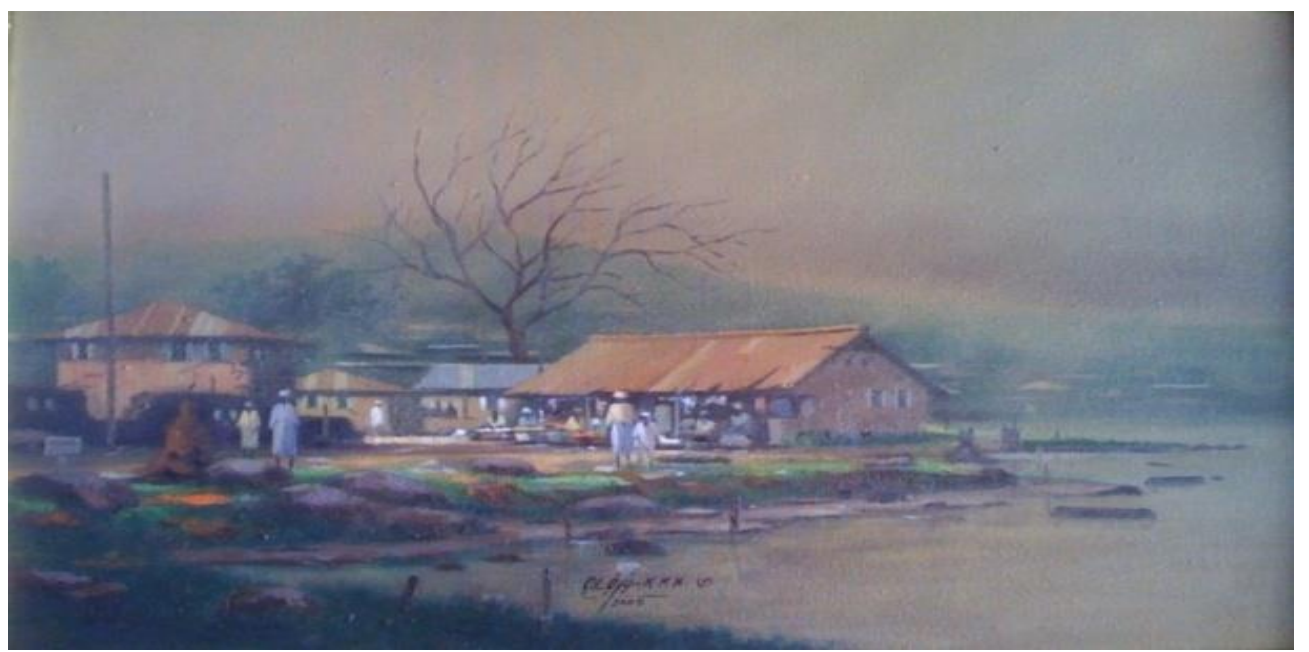

Fig. 3: At a Setting. Kazeem Olojo, Oil on Canvas, 2007, Size:200cm x 130cm. (C) Olojo's Collection

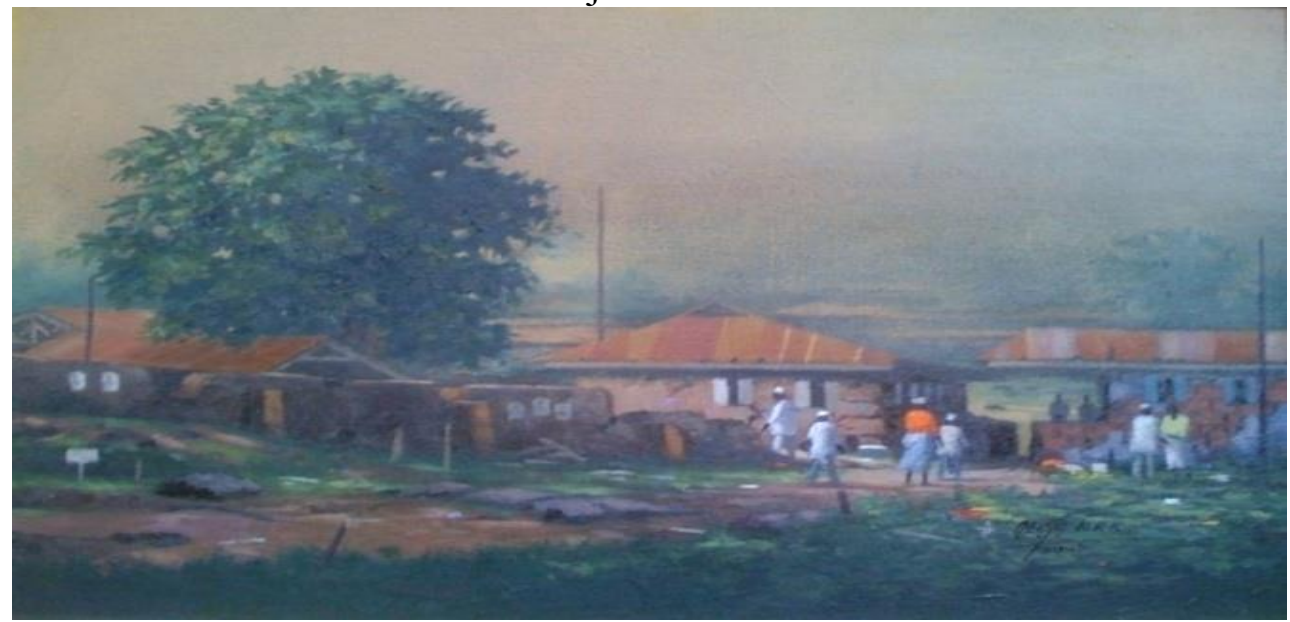

Fig. 4: Evening Mood. Kazeem Olojo, Oil on Canvas, 2008, Size: $200 \mathrm{~cm}$ x $150 \mathrm{~cm}$.

(C) Olojo's Collection

In At a Setting (Fig. 3), the artist presents a rural community in which people are moving in a relaxed mood. He situates the houses in clusters unlike in his Reflections of a Setting (Fig. 1). The clustering of beautiful buildings by the sea side makes the painting more exciting. In Evening Mood (Fig. 4) Kazeem Olojo presents a typical environmental mood of relaxation in which people dress casually, walking up and down the community probably to visit friends and families. He paints trees and vegetation to create a rural setting. Bolade Fruit Market (Fig. 5) shows buildings that are used as warehouses for selling and 
buying fruits. He creates a sfumato effect on a smoke-like haziness with subtle outlines to reflect an atmospheric condition of the market milieu.

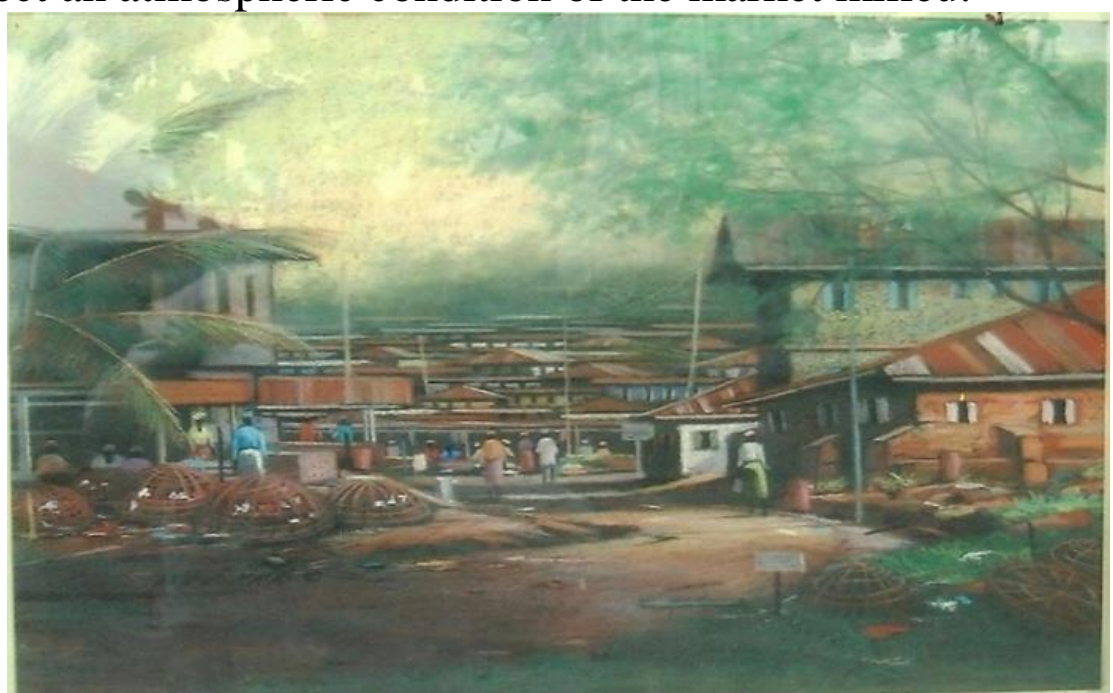

Fig. 5: Bolade Fruit Market. Kazeem Oloj,. Oil on Canvas, 2008, Size: $200 \mathrm{~cm}$ x $120 \mathrm{~cm}$.

(C) Olojo's Collection

Olojo executes another market scene, Idumota Market (Fig. 6), where he shows a vivid expression of a beautiful market with old buildings and a small river at the foreground. The market women are depicted moving up and down, preparing for a long day marketing activities (The Guardian, 2007, p. 85). A Feel of Egbede (Fig. 8) follows this series of environmental paintings, and it is rendered as a superb composition. It depicts a typical rural community that has a tarred road which is the only link road that leads to all other communities in the area. In At a Setting II (Fig. 8) the artist continues his community exploration by painting beautiful scenery of rusty roofs and moving human figures. In it, he captures an atmosphere that has nuances that are common to typical Yoruba towns (Resurgence, An Exhibition Catalogue, 2006, p. 17).

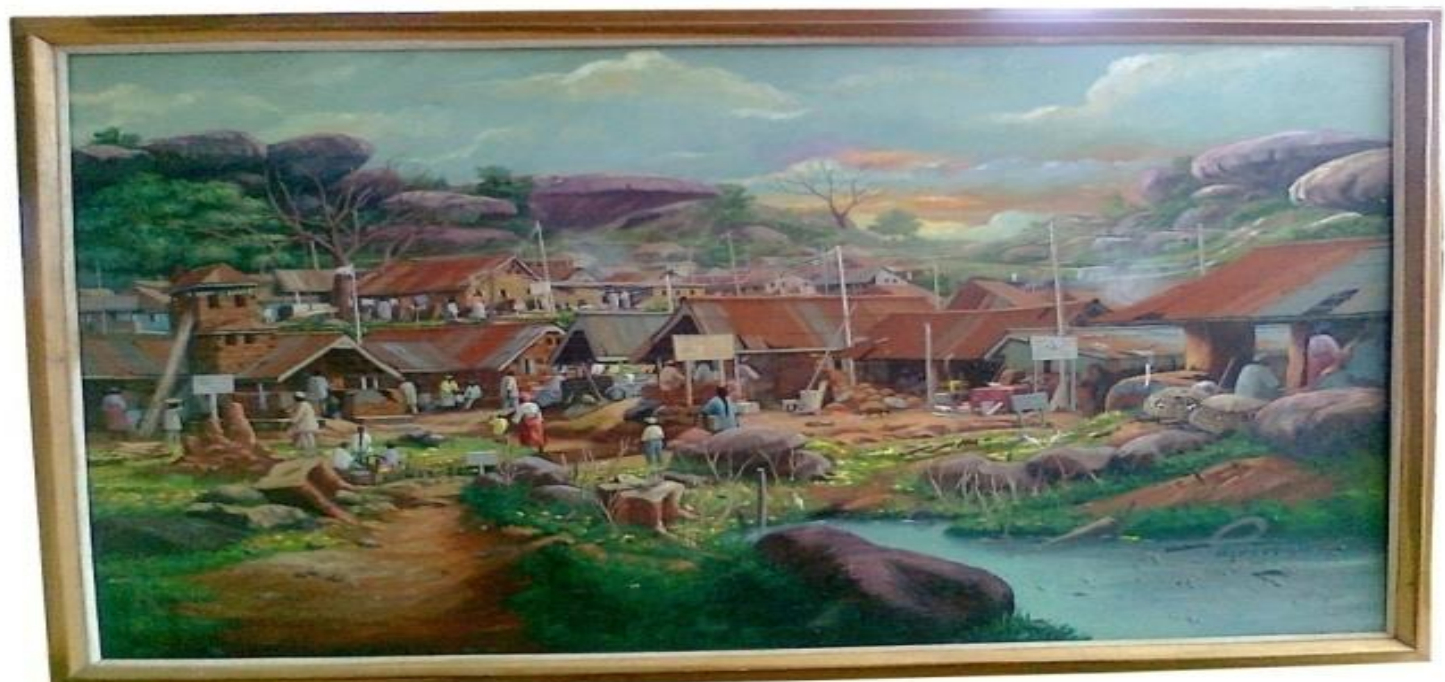

Fig. 6: Idumota Market. Kazeem Olojo. Oil on Canvas, 2008, Size: $200 \mathrm{~cm}$ x $200 \mathrm{~cm}$. () Olojo's Collection 


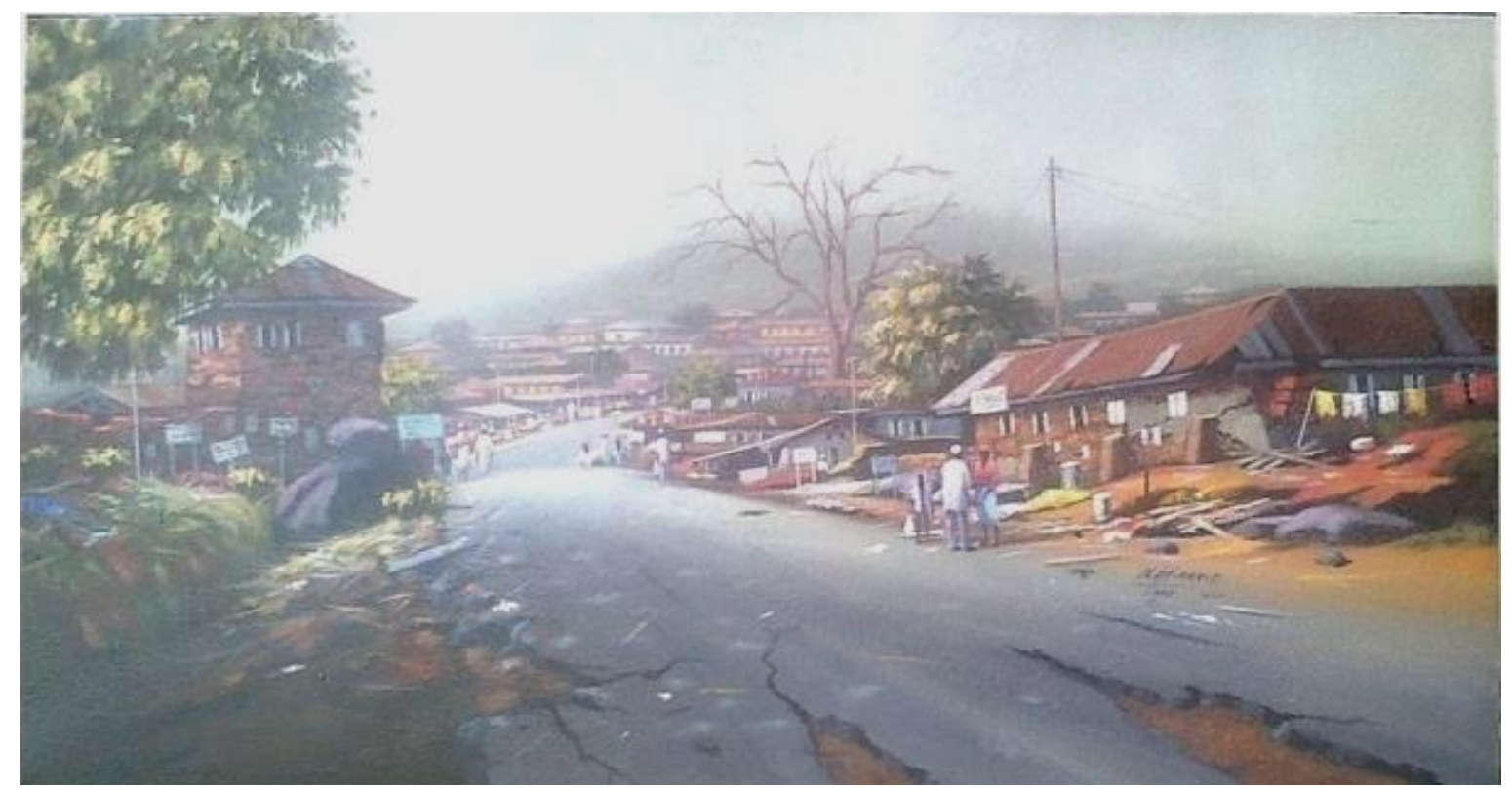

Fig. 7: A Feel of Egbede. Kazeem Olojo. Oil on Canvas, 2009, Size: 200cm x 150cm, (C) Olojo's Collection

Kazeem Olojo in Okpe Spirit (Fig. 9), moves completely into another realm of social life and leaves the rural community scenery. He presents Okpe Spirit with gestural movement and fluid lines. The figure is masked in unique attire with a hat to match. He significantly positions the figure in an action packed encounter (Ibid. p. 18). It is adorned in a white trouser and a yellow shirt. Oke-Ila Reflection (Fig. 10) is another well composed and busy setting. The marketers are shown delivering assorted fruits to a typical Yoruba rural market. The movement of women, trading to ensure a profitable gain at the end of the day, is captured in a somewhat atmospheric mood. The colours are real and inviting; an evidence of Olojo's consolidation of realism (Adenugba, 2008, p.5).

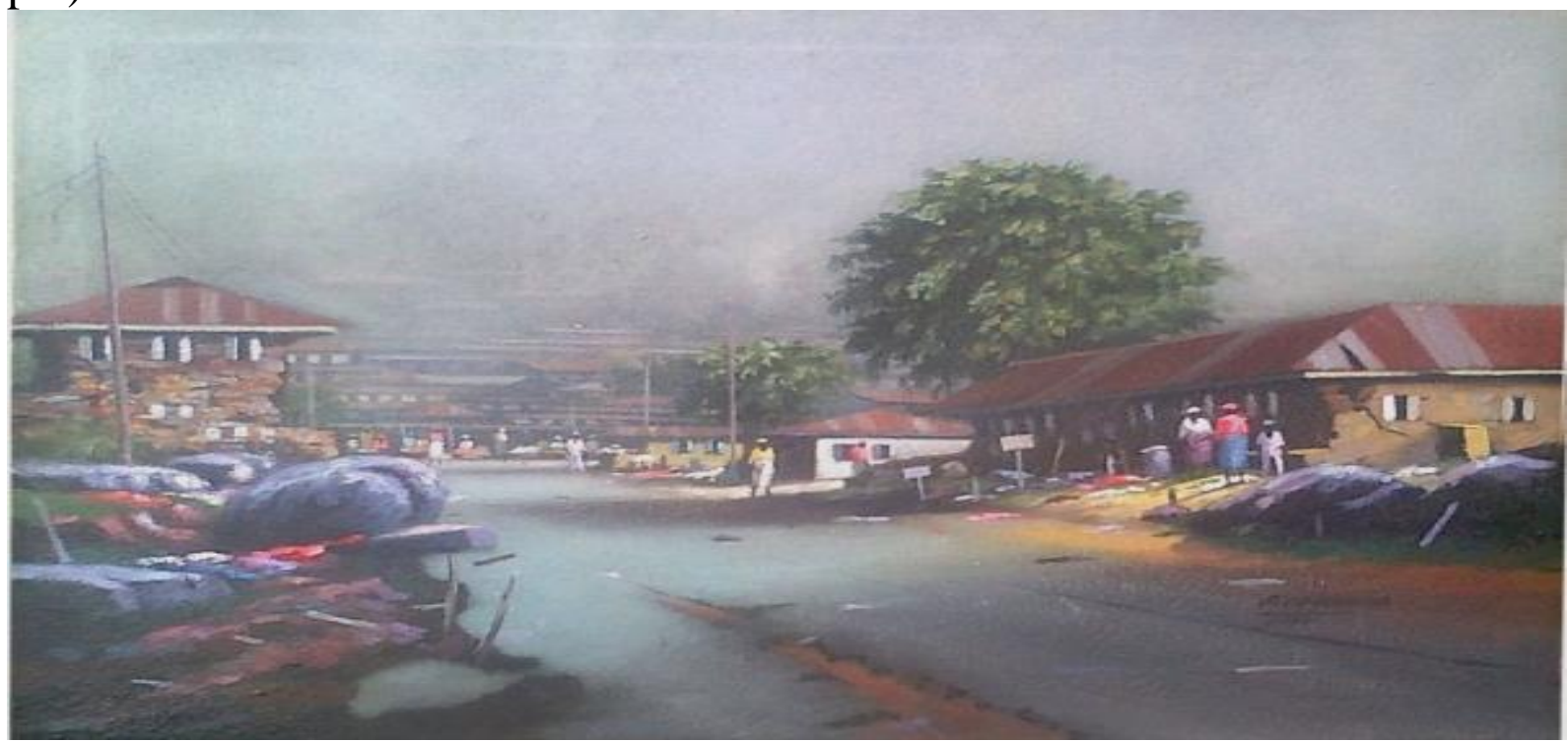

Fig. 8: At a Setting II. Kazeem Olojo. Oil on Canvas, 2009, Size: $200 \mathrm{~cm}$ x $120 \mathrm{~cm}$. (C) Olojo's Collection 


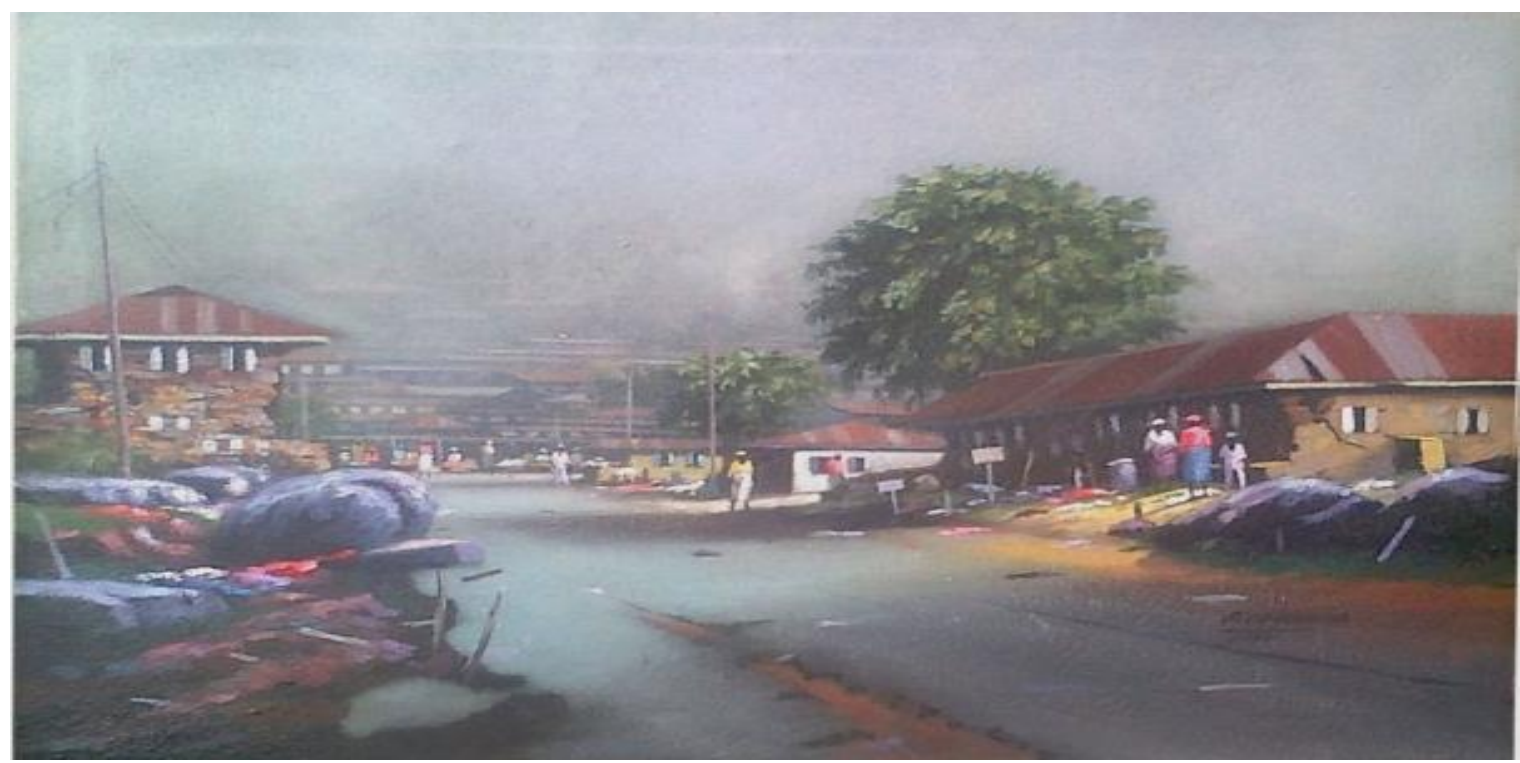

Fig. 8: At a Setting II. Kazeem Olojo. Oil on Canvas, 2009, Size: 200cm x 120cm. (C) Olojo's Collection

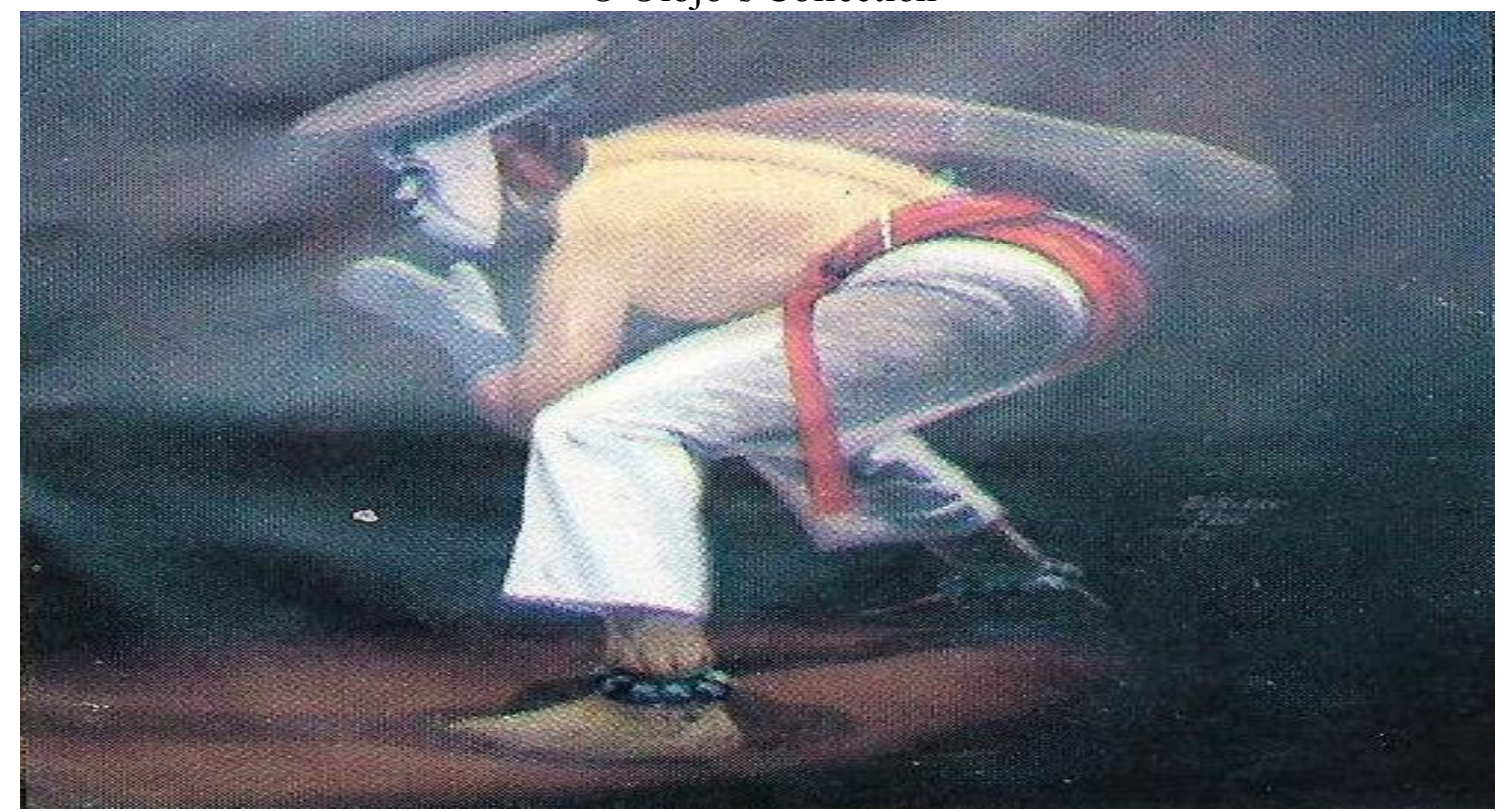

Fig. 9: Okpe Spirit. Kazeem Olojo. Oil on Canvas, 2008, Size: $120 \mathrm{~cm}$ x $110 \mathrm{~cm}$. (C) Universal Studios of Art

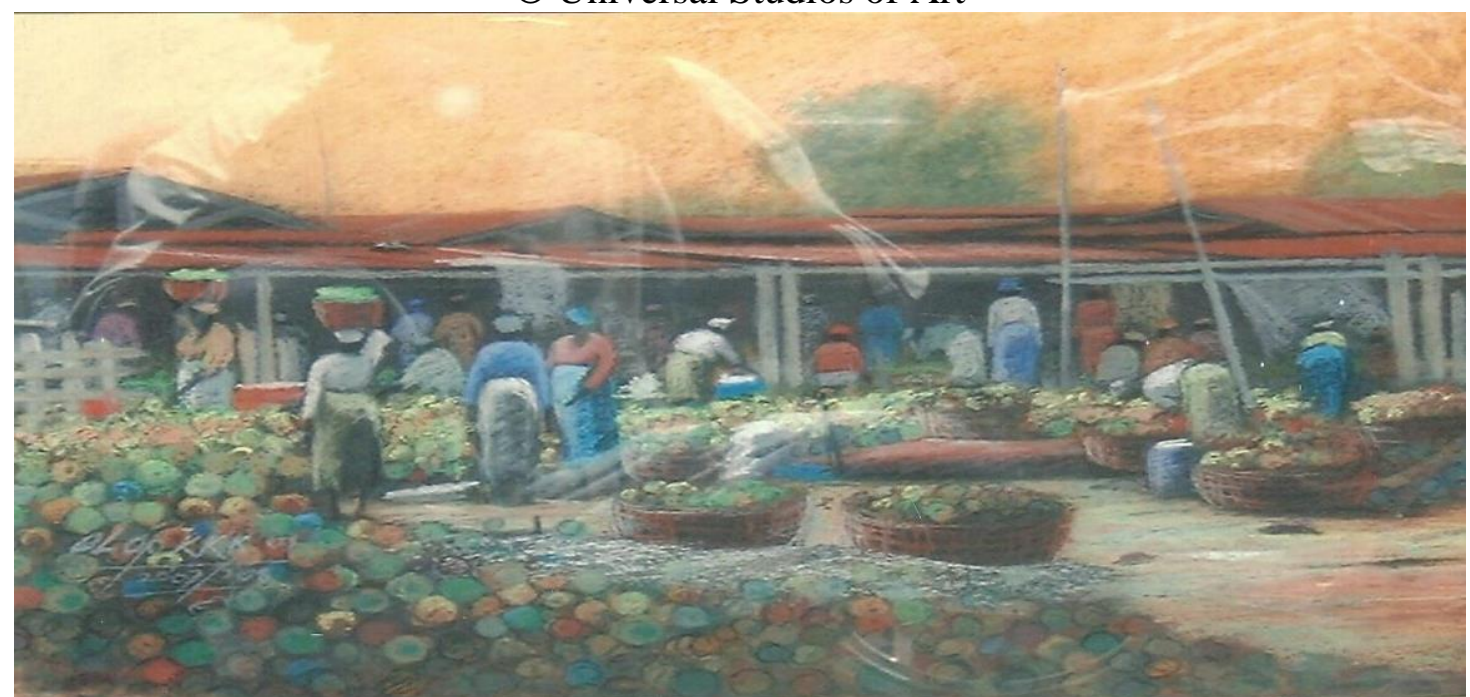

Fig. 10: Oke-Ila Reflection (Osun State). Kazeem Olojo, Oil on Canvas, Size: $120 \mathrm{~cm}$ x 110. (C) Universal Studios of Art 
Olojo's artistic skills have improved by the day, and this, no doubt, qualifies him as an instructor at the Universal Studios of Art where he has been since 2006. He displays diversity of methods and stylistic tendencies in his debut paintings, while his myriads of techniques and styles are inspired by diverse sources. He acquired artistic training from different hands during the course of his practice and studies (Bunmi, 2010, pp. 3-4). An Exhibition Catalogue, 2005, pp. 15-16). To date, he has had one solo and many group exhibitions locally and internationally. He is a member of the Society of Nigerian Artists (S.N.A), Lagos State branch. This devout Christian is married with children.

\section{Conclusions}

The pioneering efforts of Aina Onabolu and Kenneth Murray down to the creative input of the Mbari-Mbayo in Oshogbo, Ife, Ibadan and others, have roots of art which have metamorphose to more schools and workshops of apprenticeship. The Abayomi Barber, the Bruce Onabrakpeya Harmattan experimental workshop, the Universal Studios of Art, Lagos where fortunately Kazeem Olojo had his tutorship and tutelage would not be easily forgotten. Olojo's vivid expression of environmental paintings depicting typical rural community markets of Idumota market, Bolade Fruit market, Reflections of a Setting, Evening Mood, and others, clearly establish Kazeem as a painter with pictorial realism and precision. He remain no doubt an artist of high grade and as an instructor at the Universal Studios of Art, Lagos, his quality art experimentations and styles have benefitted both the formal and the informal participants and students on Industrial Training for some years now. His constant activities and would surely benefit more who would be fortunate to go through his experimental tutelage not only in the studios, but also as he organizes workshops and seminars around Lagos city and its environs every year.

\section{Bibliography}

1. Adenugba, B. (2008). Rejuvenation. An Exhibition Catalogue of Contemporary Nigerian Art by the Society of Nigerian Artists, Lagos, 24 June-8 July, (Lagos: National Gallery of Art), p. 5.

2. An interview with Kazeem Olojo (Painter), Universal Studios of Art, Lagos, September, 2007 and October, 2011.

3. An interview with Kazeem Olojo (Painter), Universal Studios of Art, Lagos, September, 2007 and October, 2011.

4. Bardi, A. (2014). Art, Professionality and the Artists of the Universal Studios of Art, Lagos, 1980-2013. Unpublished PhD dissertation. University of Nigeria, Nsukka. p. 223.

5. Bunmi, B. (2010). A Handbook on the Universal Studios of Art Artists. pp. 34. 
6. Kremarikova, Z.T. \& Kovacova, B. (2016). Evalua tion of an Art Therapy programme for clients with different life situations. Review of Artistic Education, 11/12, 277-278.

7. Maduka, C. (1999). Art, Nature and Meaning. Unpublished Manuscripts, Department of History and International Studies, University of Benin, Benin City, p. 20.

8. Pașca, E.M. (2015). A new vision of music education from an intercultural perspective for Rroma and non Rroma students. Review of Artistic Education, 11-12, 323-328.

9. Resurgence. An Exhibition Catalogue of Paintings, Sculptures and Drawings by the Universal Studios of Art, Lagos, 8-18 April, (Lagos: Terra Kulture Gallery, 2006), p. 17, 18.

10. The Guardian, Tuesday, October 18, 2007. "Harvest in Due Season with USA" Artists", p. 85. 